Cancer Immunol. Immunother. 4, 87-94 (1978)

\title{
Immunologic Monitoring and Immunotherapy in Ewing's Sarcoma
}

\author{
R. L. Richardson ${ }^{1}$, R. K. Oldham ${ }^{1}$, T. C. Pomeroy², J. L. Weese ${ }^{3}$, J. L. McCoy, G. B. Cannon, J. H. Dean, and \\ R. B. Herberman ${ }^{4}$ \\ Laboratory of Immunodiagnosis and Radiation Oncology Branch, National Cancer Institute, \\ Bethesda, Maryland 20014, USA \\ Department of Immunology, Litton-Bionetics, Inc., \\ Kensington, Maryland 20795, USA
}

\begin{abstract}
Summary. Serial immunological monitoring was performed on 31 patients with Ewing's sarcoma who were on a randomized immunotherapy trial with $B C G$ administered by dermal scarification with a Heaf gun. $\mathrm{Pa}$ tients were skin-tested for delayed hypersensitivity reactions (DCHR) to recall antigens and extracts of tumor cells, and with keyhole limpet hemocyanin (KLH). In vitro testing consisted of lymphocyte counts, percentages of cells forming rosettes with sheep erythrocytes at $29^{\circ}$ $C$ and at $4^{\circ} C$, and leukocyte migration inhibition to tuberculin (PPD) and to $3 \mathrm{M} \mathrm{KCl}$ extracts of tumor cells. At the time of diagnosis, nearly all patients had positive DCHR to mumps and streptococcal antigens and were negative to PPD. Neither the skin tests nor the lymphocyte counts at this time gave useful prognostic information. In tests during and after therapy, the patients who responded and remained free of detectable disease had a higher incidence of DCHR to KLH and of rosette values in the normal range than did the patients who developed recurrent disease. The BCG immunotherapy had no apparent effect on immunologic parameters except for conversion of reactions to PPD.
\end{abstract}

\section{Introduction}

Ewing's sarcoma is a highly malignant undifferentiated tumor arising in bone and, rarely, in soft tissues (Angervall and Enzinger, 1975). It is an uncommon tumor,

\footnotetext{
${ }^{1}$ Present address: Division of Oncology, Department of Medicine, Vanderbilt University, Nashville, Tenn. 37232, USA

${ }^{2}$ Present address: University of Texas Health Science Center, San Antonio, Texas 78229, USA

${ }^{3}$ Present address: Department of Surgery, University of Michigan, Ann Arbor, Mich. 48109, USA

${ }^{4}$ Reprint requests should be addressed to: Ronald B. Herberman, Laboratory of Immunodiagnosis, National Cancer Institute, Building 10, Room 8B11, Bethesda, Maryland 20014, USA
}

accounting for about $10 \%$ of all malignant primary bone tumors, but nevertheless, after osteogenic sarcoma, it is the most common malignant primary bone neoplasm. When treated by either surgical resection or local radiotherapy alone, there is an equally grim prognosis: about $50 \%$ of such patients relapse with distant metastases within 12 months (Sutow and Martin, 1974) and fewer than 10\% survive 5 years (Johnson and Pomeroy, 1972; Falk and Alpert, 1967; Rosen et al., 1974). Because of the high probability of occult metastases being present at the time of diagnosis, most centers now combine local radiotherapy to the primary lesion with adjuvant chemotherapy. Such therapeutic strategies have resulted in impressive improvements in both remission duration and 5-year survival rates (Rosen et al., 1974; Johnson and Pomeroy, 1975; Jaffe et al., 1976). Of 125 Ewing's sarcoma patients treated at the National Cancer Institute since $1964,70 \%$ were alive at 2 years and $16 \%$ survived 5 years after treatment. For patients without clinical evidence of metastases at diagnosis the figures are even more striking: of 46 patients treated with radiotherapy to the primary lesion and with adjuvant chemotherapy (cyclophosphamide, doxorubicin, and vincristine), $70 \%$ are disease-free and $89 \%$ are alive 30 months after completion of treatment.

We previously reported a correlation between the presence of perivascular infiltrates of small lymphocytes in the supporting stroma of Ewing's sarcoma and subsequent survival (Pomeroy and Johnson, 1975). Because of this suggestion of the role of the immune response in this disease and because of our interest in the immunologic status of cancer patients, in 1974 we began a study of immunologic monitoring and immunotherapy in Ewing's sarcoma. This report describes our findings with a variety of in vivo and in vitro assays of immune reactivity in such patients. A number of patients were treated with immunostimulants, and the effects of this therapy were monitored by observation of their clinical courses in addition to their immunologic responses. 


\section{Materials and Methods}

61 patients with Ewing's sarcoma were studied over a 2-year period at the National Cancer Institute. For the purposes of this study these patients were classified into the following groups:

Group A: Patients without clinical evidence of metastases at diagnosis and no evidence of tumor recurrence after completion of therapy ( 29 patients).

Group B: Patients without clinical evidence of metastases at diagnosis but tumor recurrence after completion of therapy (17 patients).

Group C: Patients with clinically apparent metastases at diagnosis (15 patients).

Treatment regimens have been described by Johnson and Pomeroy (1976). All patients were treated with chemotherapy in combination with $5000 \mathrm{R}$ to the primary site, given over a period of five weeks. 55 patients were treated with the $\mathrm{S} 4$ protocol (doxorubicin, cyclophosphamide, vincristine, and CNS prophylactic irradiation). Because of the poor prognosis of patients with metastatic disease, particularly those with bulky tumors, a number of group $C$ patients were treated with an accelerated $\mathrm{S} 4$ regimen utilizing the same radiotherapy and CNS prophylaxis plus a more intensive chemotherapeutic program employing the same three drugs given together every 3 weeks. Six patients were treated according to earlier protocols; three of these were treated according to the $\mathrm{S} 3$ protocol, with CNS prophylactic irradiation plus cyclophosphamide, vincristine, and dactinomycin; two according to $\mathrm{S} 2$ with cyclophosphamide and vincristine; and one according to $\mathrm{S} 1$ with cyclophosphamide.

In addition to radio- and chemotherapy, 11 group $C$ patients were randomized to receive immunotherapy with either BCG (bacille Calmette Guérin) or BCG plus allogeneic irradiated tumor cells. Nine patients in group B were also treated with BCG immunotherapy, with or without irradiated allogeneic tumor cells. Finally, nine patients with clinically localized disease who were at high risk for recurrence by virtue of either truncal location of the primary tumor (Pomeroy and Johnson, 1975) or a serum lactate dehydrogenase (LDH) level greater than 200 IU (Brereton et al., 1975) were randomized to BCG immunotherapy or no further therapy, in addition to radiotherapy and adjuvant chemotherapy.

BCG was administered by dermal scarification using a 20-point Heaf gun. Lyophilized Pasteur BCG, $6 \pm 4 \times 10^{8}$ viable organisms per vial, was diluted in less than $1 \mathrm{ml}$ of normal saline and applied to an area of skin $5 \times 5 \mathrm{~cm}$ for each scarification. BCG was given on days 14, 28, and 42 of each 49-day chemotherapy cycle, and for patients with recurrent or progressive disease at day 14 of the 21-day chemotherapy cycle. Immunizations were given in a single extremity, and the immunization sites were rotated sequentially, avoiding extremities treated by radiotherapy. Patients treated with BCG plus allogeneic tumor cells received BCG in identical fashion. Allogeneic cells were obtained at surgery or necropsy under sterile conditions from metastatic sites, manually dispersed, suspended in tissue culture medium with $10 \%$ dimethylsulfoxide, and stored in vapor-phase liquid nitrogen. Cell preparations were cultured for possible bacterial contamination, and only used when found to be sterile. Prior to injection the thawed cell suspension was irradiated with $5000 \mathrm{R}$, and $10^{7}$ allogeneic cells were injected intradermally and subcutaneously $1 \mathrm{~cm}$ from the margin of the last BCG inoculation. The intention was to have the major lymph node groups stimulated with $B C G$ prior to injection of the allogeneic tumor cells, and to have a separate site for the cell inoculum to permit observation, in the unlikely event that the injected cells might grow.

\section{Delayed Cutaneous Hypersensitivity (DCH)}

Intradermal testing for delayed hypersensitivity was performed when possible prior to therapy and at 3-month intervals both during and following therapy. All patients were tested with one or more of the following standard recall antigens: streptokinase-streptodornase (40 U SK, $10 \mathrm{U} \mathrm{SD} / 0.1 \mathrm{ml}$, Varidase, Lederle Laboratories Division, American Cyanamid Co., Pearl River, N.Y. 10965), PPD (5 TU/0.1 $\mathrm{ml}$, Parke Davis, Detroit, Mich. 48232), and mumps (20 U/0.1 ml, Eli Lilly and Co., Indianapolis, Ind. 46206). Patients were also tested for DCH to hypotonic membrane preparations (HMP) (Oren and Herberman, 1971) and $3 \mathrm{M} \mathrm{KCl}$ extracts (McCoy et al., 1975) of a Ewing's sarcoma (5838) obtained from pleural fluid at necropsy and of the established tissue culture line $(5838 \mathrm{TC})$ derived from this specimen. After testing for sterility, $0.1 \mathrm{mg}$ protein $/ 0.1 \mathrm{ml}$ quantities of these preparations were injected intradermally.

To assess the ability to respond to a new antigen, keyhole limpet hemocyanin (KLH), generously supplied by Dr. Michael Blaese, Metabolism Branch, NCI, $2.5 \mathrm{mg} / 0.5 \mathrm{ml}$ was injected subcutaneously prior to chemotherapy, and the response to $0.1 \mathrm{mg} / 0.1 \mathrm{ml} \mathrm{KLH}$ injected intradermally was determined in the same manner as for the other antigens.

$\mathrm{DCH}$ responses were read $48 \mathrm{~h}$ following intradermal injection of antigen using a ball-point pen technique similar to that described by Sokal (1975). Readings were recorded in $\mathrm{mm}$ of induration, and a skin test for any antigen was considered positive if it was $5 \mathrm{~mm}$ or greater in diameter.

\section{Direct Leukocyte Migration Inhibition}

Leukocyte migration inhibition (LMI) by either PPD or $3 \mathrm{M} \mathrm{KCl}$ extracts of the 5838 tumor or of the $5838 \mathrm{TC}$ cell line was performed as described by McCoy et al. (1977). The migration index (MI) was calculated according to the formula

mean migration area of 4 replicates in presence of antigen $\mathrm{MI}=\frac{}{\text { mean migration area of } 4 \text { replicates in absence of antigen }}$

Migration indices of patients were compared to those of normals, and the number of positive MIs was determined, as previously described (McCoy et al., 1977), by means of a cutoff value calculated so that $10 \%$ of normal MIs fell below this value. MIs falling below this cutoff were considered positive, i.e., below the lower tenth percentile of normals. Cutoff values were determined individually for PPD and for the $3 \mathrm{M} \mathrm{KCl}$ extracts of 5838 and $5838 \mathrm{TC}$.

\section{Rosettes}

Thymus-dependent lymphocytes were assayed when possible prior to therapy and at monthly intervals by determination of spontaneous rosette formation with sheep red blood cells (SRBC) at $4^{\circ} \mathrm{C}$ and at $29^{\circ} \mathrm{C}$ as previously described (West, 1978; West et al., 1976). Venous blood specimens were drawn prior to the administration of the next course of chemotherapy or after completion of chemotherapy. In our laboratory, normal donors tested for $4^{\circ} \mathrm{C} \mathrm{RFC}$ and $29^{\circ} \mathrm{C}$ RFC by these techniques had a mean of $76 \%$ and $53 \%$, respectively (Djeu et al., in press). Values falling below the tenth percentile of normals, $67 \%$ for $4^{\circ} \mathrm{C} \mathrm{RFC}$ and $47 \%$ for $29^{\circ} \mathrm{C} \mathrm{RFC}$, were considered depressed.

\section{Results}

Prognostic Value of Tests Performed before or during Therapy

We were interested in whether $\mathrm{DCH}$ responses to recall antigens and TAAs at the time of diagnosis might be of some prognostic value. Table 1 summarizes these re- 
Table 1. DCH in Ewing's sarcoma patients tested at diagnosis

\begin{tabular}{llllllll}
\hline & & SKSD & Mumps & PPD & $5838 \mathrm{KCl}$ & $\begin{array}{l}5838 \mathrm{TC} \\
\mathrm{KCl}\end{array}$ & $5838 \mathrm{HMP}$ \\
\hline Group A: 14 patients & $\begin{array}{l}\text { Number of patients } \\
\text { reactive/total tested } \\
\text { (\%) }\end{array}$ & $13 / 13$ & $3 / 3$ & $2 / 14$ & $7 / 8$ & $8 / 11$ & $2 / 11$ \\
& $\begin{array}{l}\text { Number of patients } \\
\text { Group B: } 5 \text { patients }\end{array}$ & $4 / 4$ & $2 / 2$ & $0 / 4$ & $1 / 1$ & $0 / 1$ & $(18)$ \\
& $\begin{array}{l}\text { reactive/total tested } \\
(\%)\end{array}$ & $(100)$ & $(100)$ & $(0)$ & $(100)$ & $(0)$ & $(1 / 3$ \\
Group C: 7 patients & $\begin{array}{l}\text { Number of patients } \\
\text { reactive/total tested } \\
(\%)\end{array}$ & $5 / 5$ & $2 / 3$ & $0 / 7$ & $1 / 1$ & $2 / 3$ & $(33)$ \\
& $(100)$ & $(67)$ & $(0)$ & $(100)$ & $(67)$ & $(33)$ \\
\hline
\end{tabular}

Table 2. Relationship of absolute lymphocyte count at diagnosis to clinical course

\begin{tabular}{|c|c|c|c|c|c|}
\hline & Lymphocytes $/ \mathrm{mm}^{3}$ & Group A & Group B & $\begin{array}{l}\text { All patients with } \\
\text { localized disease } \\
\text { at diagnosis }\end{array}$ & Group C \\
\hline $\begin{array}{l}\text { Number of patients in range/number of } \\
\text { patients in group (\%) }\end{array}$ & $\begin{aligned}< & 1000 \\
& 1000-2000 \\
> & 2000\end{aligned}$ & $\begin{aligned} 4 / 29 & (14) \\
16 / 29 & (55) \\
9 / 29 & (31)\end{aligned}$ & $\begin{array}{ll}1 / 16 & (6) \\
6 / 16 & (38) \\
9 / 16 & (56)\end{array}$ & $\begin{array}{rr}5 / 45 & (11) \\
22 / 45 & (49) \\
18 / 45 & (40)\end{array}$ & $\begin{array}{ll}4 / 13 & (31) \\
6 / 13 & (46) \\
3 / 13 & (23)\end{array}$ \\
\hline
\end{tabular}

Table 3. KLH skin test responses $\geq 15 \mathrm{~mm}$ induration during therapy

\section{Group A}

Number of patients reactive/total tested (\%) $\quad 10 / 12 \quad(83)$

Number of tests $(+) /$ total tests (\%) $13 / 17 \quad(76)$

Group B

Number of patients reactive/total tested (\%) $\quad 3 / 6 \quad(50)$

Number of tests $(+) /$ total tests (\%) $\quad 7 / 12 \quad(58)$

Group C

Number of patients reactive/total tested (\%) $\quad 3 / 7 \quad$ (43)

Number of tests $(+) /$ total tests (\%) $\quad 3 / 10 \quad(30)$

Differences between groups are not significant by chi-square analysis

sults. Nearly all patients were reactive to SKSD and mumps and nonreactive to PPD. Few patients in groups $\mathrm{B}$ and $\mathrm{C}$ were tested with TAAs at diagnosis, but $\mathrm{DCH}$ responses to the TAAs at diagnosis roughly corresponded to the overall pattern of reactivity of each patient group. No pattern of reactivity distinguished patients with localized disease from those with metastases nor did it identify patients who would later relapse.

Preliminary data had suggested that patients with total lymphocyte counts less than 1000 per $\mathrm{mm}^{3}$ or greater than 2000 per $\mathrm{mm}^{3}$ prior to treatment had a poorer prognosis than patients with counts in the range of $1000-2000$ per $\mathrm{mm}^{3}$. However, as shown in Table 2, pre-therapy lymphocyte counts between 1000 and 2000 per $\mathrm{mm}^{3}$ failed to indicate a significant pronostic benefit to non-metastatic patients and similarly failed to discriminate between patients with metastatic versus nonmetastatic disease.

In contrast to the lack of prognostic value of total lymphocyte counts and initial DCH responses to standard recall and tumor-associated antigens, the magnitude of the delayed hypersensitivity response to $\mathrm{KLH}$ during treatment appeared to distinguish patients in group A from those in groups B and C. As shown in Table 3, most of the patients in group $\mathrm{A}$ and fewer in groups $B$ and $C$ had responses to $\mathrm{KLH}$ of $15 \mathrm{~mm}$ or greater.

The results of skin tests of all antigens and of direct LMI during therapy in patients with localized disease are shown in Table 4. All patients who remained free of disease were reactive to KLH, SKSD, or mumps, and with the exception of a single negative mumps test, all of the responses to these antigens were positive. In contrast, several patients who later relapsed were unreactive to these antigens. Skin test reactivity to the tumor extracts was similar for the disease-free patients and those who had recurrences, and corresponded to the overall reactivity to these antigens. LMI reactivity during therapy of group A patients was roughly equal to the overall responses for this group to the $3 \mathrm{M} \mathrm{KCl} \mathrm{extract} \mathrm{of} 5838$ $\mathrm{TC}$; too few group B patients were tested during primary therapy to permit assessment of their LMI responses. Four of seven group A patients reacted to PPD 
Table 4. Immunologic reactivity during therapy and subsequent clinical course of patients with localized disease

\begin{tabular}{|c|c|c|c|c|c|c|c|}
\hline & \multicolumn{7}{|c|}{ Delayed cutaneous hypersensitivity } \\
\hline & $\mathrm{KLH}$ & SKSD & Mumps & PPD & $5838 \mathrm{KCl}$ & $5838 \mathrm{TC} \mathrm{KCl}$ & 15838 HMP \\
\hline \multicolumn{8}{|l|}{ Group A } \\
\hline Number of patients reactive/total tested (\%) & $\begin{array}{l}14 / 14 \\
(100)\end{array}$ & $\begin{array}{l}10 / 10 \\
(100)\end{array}$ & $\begin{array}{l}1 / 1 \\
(100)\end{array}$ & $\begin{array}{l}3 / 7 \\
(43)\end{array}$ & $\begin{array}{l}7 / 7 \\
(100)\end{array}$ & $\begin{array}{l}5 / 9 \\
(56)\end{array}$ & $\begin{array}{l}2 / 9 \\
(22)\end{array}$ \\
\hline Number of $(+)$ tests/total tests (\%) & $\begin{array}{l}19 / 19 \\
(100)\end{array}$ & $\begin{array}{l}14 / 14 \\
(100)\end{array}$ & $\begin{array}{l}1 / 2 \\
(50)\end{array}$ & $\begin{array}{l}4 / 11 \\
(36)\end{array}$ & $\begin{array}{c}7 / 8 \\
(88)\end{array}$ & $\begin{array}{l}5 / 9 \\
(56)\end{array}$ & $\begin{array}{l}2 / 12 \\
(17)\end{array}$ \\
\hline \multicolumn{8}{|l|}{ Group B } \\
\hline Number of patients reactive/total tested (\%) & $\begin{array}{l}3 / 4 \\
(75)\end{array}$ & $\begin{array}{l}4 / 5 \\
(80)\end{array}$ & $\begin{array}{l}0 / 1 \\
(0)\end{array}$ & $\begin{array}{l}1 / 5 \\
(20)\end{array}$ & $\begin{array}{l}3 / 3 \\
(100)\end{array}$ & $\begin{array}{l}2 / 3 \\
(67)\end{array}$ & $\begin{array}{l}1 / 4 \\
(25)\end{array}$ \\
\hline \multirow[t]{4}{*}{ Number of $(+)$ tests/total tests (\%) } & $\begin{array}{l}9 / 12 \\
(75)\end{array}$ & $\begin{array}{l}6 / 7 \\
(86)\end{array}$ & $\begin{array}{l}0 / 1 \\
(0)\end{array}$ & $\begin{array}{l}1 / 8 \\
(13)\end{array}$ & $\begin{array}{l}4 / 4 \\
(100)\end{array}$ & $\begin{array}{l}3 / 6 \\
(50)\end{array}$ & $\begin{array}{l}1 / 7 \\
(14)\end{array}$ \\
\hline & \multicolumn{7}{|c|}{ Leukocyte migration inhibition } \\
\hline & \multirow{2}{*}{$\begin{array}{l}5838 \mathrm{TC} \\
(50 \mu \mathrm{g} / \mathrm{ml})\end{array}$} & & \multirow{2}{*}{$\begin{array}{l}5838 \mathrm{TC} \\
(1 \mu \mathrm{g} / \mathrm{ml})\end{array}$} & \multicolumn{4}{|c|}{ PPD $(25 \mu \mathrm{g} / \mathrm{ml})$} \\
\hline & & & & Total & & $\begin{array}{l}\text { With } \mathrm{BCG}^{\mathrm{a}} \\
\text { therapy }\end{array}$ & $\begin{array}{l}\text { No } B C G \\
\text { therapy }\end{array}$ \\
\hline \multicolumn{8}{|l|}{ Group A } \\
\hline Number of patients reactive/total tested (\%) & $\begin{array}{l}9 / 10 \\
(90)\end{array}$ & \multicolumn{2}{|r|}{$\begin{array}{l}5 / 7 \\
(71)\end{array}$} & \multicolumn{2}{|l|}{$\begin{array}{l}4 / 7 \\
(57)\end{array}$} & $\begin{array}{l}2 / 2 \\
(100)\end{array}$ & $\begin{array}{l}2 / 5 \\
(40)\end{array}$ \\
\hline Number of $(+)$ tests/total tests (\%) & $\begin{array}{l}31 / 44 \\
(70)\end{array}$ & \multicolumn{2}{|r|}{$\begin{array}{l}5 / 9 \\
(56)\end{array}$} & \multicolumn{2}{|l|}{$\begin{array}{l}5 / 9 \\
(56)\end{array}$} & $\begin{array}{l}2 / 3 \\
(67)\end{array}$ & $\begin{array}{l}3 / 6 \\
(50)\end{array}$ \\
\hline \multicolumn{8}{|l|}{ Group B } \\
\hline Number of patients reactive/total tested (\%) & $\begin{array}{l}1 / 1 \\
(100)\end{array}$ & \multicolumn{2}{|r|}{-} & \multicolumn{2}{|l|}{$\begin{array}{l}1 / 1 \\
(100)\end{array}$} & $\begin{array}{l}1 / 1 \\
(100)\end{array}$ & - \\
\hline Number of $(+)$ tests/total tests $(\%)$ & $\begin{array}{l}2 / 2 \\
(100)\end{array}$ & \multicolumn{2}{|r|}{$\begin{array}{l}0 / 0 \\
(0)\end{array}$} & \multicolumn{2}{|l|}{$\begin{array}{l}1 / 1 \\
(100)\end{array}$} & $\begin{array}{l}1 / 1 \\
(100)\end{array}$ & - \\
\hline
\end{tabular}

a Patients who had received BCG as part of either their primary therapy or anti-tuberculosis immunization programs

Table 5. Lymphocyte subpopulations during therapy of patients with localized disease

\begin{tabular}{|c|c|c|c|c|c|c|c|c|}
\hline $\begin{array}{l}\text { Absolute number of } \\
\text { lymphocytes per } \mathrm{mm}^{3}\end{array}$ & $\begin{array}{l}\text { Number of } \\
\text { tests in } \\
\text { range/total tests }\end{array}$ & $(\%)$ & $\begin{array}{l}29^{\circ} \mathrm{C} \mathrm{RFC} \\
\%\end{array}$ & $\begin{array}{l}\text { Number of } \\
\text { tests in } \\
\text { range/total tests }\end{array}$ & $(\%)$ & $\begin{array}{l}4^{\circ} \mathrm{C} \mathrm{RFC} \\
\%\end{array}$ & $\begin{array}{l}\text { Number of } \\
\text { tests in } \\
\text { range/total tests }\end{array}$ & $(\%)$ \\
\hline \multicolumn{9}{|l|}{ Group A } \\
\hline$<500$ & $6 / 11$ & (55) & $<25$ & $3 / 16$ & (19) & $<25$ & $0 / 8$ & $(0)$ \\
\hline $500-1000$ & $2 / 11$ & (18) & $25-47$ & $8 / 16$ & (50) & $25-67$ & $0 / 8$ & (0) \\
\hline$>1000$ & $3 / 11$ & (27) & $>47$ & $5 / 16$ & (31) & $>67$ & $8 / 8$ & (100) \\
\hline \multicolumn{9}{|l|}{ Group B } \\
\hline$<500$ & $3 / 7$ & (43) & $<25$ & $2 / 9$ & (22) & $<25$ & $0 / 2$ & $(0)$ \\
\hline $500-1000$ & $4 / 7$ & (57) & $25-47$ & $6 / 9$ & $(67)$ & $25-67$ & $2 / 2$ & $(100)$ \\
\hline$>1000$ & $0 / 7$ & (0) & $>47$ & $1 / 9$ & (11) & $>67$ & $0 / 2$ & (0) \\
\hline
\end{tabular}

in LMI, and this sensitivity could be attributed to BCG immunotherapy or to known prior sensitization.

The results of rosette assays during therapy of patients with localized disease are summarized in Table 5. Of the assays in group A patients, nearly one third of the measurements of the $29^{\circ} \mathrm{C} \mathrm{RFC}$ and all of the measurements of $4^{\circ} \mathrm{C}$ RFC and all of the measurements of $4^{\circ} \mathrm{C} \mathrm{RFC}$ subpopulations were in the normal range, in contrast to the lower percentage of normal values in the group B patients. 
Table 6. Immunologic reactivity and subsequent clinical course after initial therapy of patients with localized disease

\begin{tabular}{|c|c|c|c|c|c|c|c|}
\hline & \multicolumn{7}{|c|}{ Delayed cutaneous hypersensitivity } \\
\hline & KLH & SKSD & Mumps & PPD & $5838 \mathrm{KCl}$ & $5838 \mathrm{TC} \mathrm{KCl}$ & 5838 HMP \\
\hline \multicolumn{8}{|l|}{ Group A } \\
\hline Number of patients reactive/total tested (\%) & $\begin{array}{l}4 / 5 \\
(80)\end{array}$ & $\begin{array}{l}12 / 12 \\
(100)\end{array}$ & $\begin{array}{l}3 / 3 \\
(100)\end{array}$ & $\begin{array}{l}3 / 9 \\
(33)\end{array}$ & $\begin{array}{l}5 / 5 \\
(100)\end{array}$ & $\begin{array}{l}2 / 3 \\
(67)\end{array}$ & $\begin{array}{l}2 / 6 \\
(33)\end{array}$ \\
\hline Number of $(+)$ tests/total tests (\%) & $\begin{array}{l}4 / 5 \\
(80)\end{array}$ & $\begin{array}{l}15 / 15 \\
(100)\end{array}$ & $\begin{array}{l}3 / 3 \\
(100)\end{array}$ & $\begin{array}{l}3 / 18 \\
(17)\end{array}$ & $\begin{array}{l}8 / 8 \\
(100)\end{array}$ & $\begin{array}{l}2 / 3 \\
(67)\end{array}$ & $\begin{array}{l}2 / 6 \\
(33)\end{array}$ \\
\hline \multicolumn{8}{|l|}{ Group B } \\
\hline Number of patients reactive/total tested (\%) & $\begin{array}{l}5 / 9 \\
(56)\end{array}$ & $\begin{array}{l}12 / 14 \\
(86)\end{array}$ & $\begin{array}{l}6 / 7 \\
(86)\end{array}$ & $\begin{array}{l}6 / 14 \\
(43)\end{array}$ & $\begin{array}{l}4 / 4 \\
(100)\end{array}$ & $\begin{array}{l}6 / 6 \\
(100)\end{array}$ & $\begin{array}{l}5 / 5 \\
(100)\end{array}$ \\
\hline Number of $(+)$ tests/total tests $(\%)$ & $\begin{array}{l}9 / 14 \\
(64)\end{array}$ & $\begin{array}{l}18 / 23 \\
(78)\end{array}$ & $\begin{array}{l}7 / 10 \\
(70)\end{array}$ & $\begin{array}{l}7 / 25 \\
(28)\end{array}$ & $\begin{array}{l}4 / 4 \\
(100)\end{array}$ & $\begin{array}{l}6 / 8 \\
(75)\end{array}$ & $\begin{array}{l}4 / 15 \\
(27)\end{array}$ \\
\hline
\end{tabular}

\begin{tabular}{|c|c|c|c|c|c|}
\hline & \multicolumn{5}{|c|}{ Leukocyte migration inhibition } \\
\hline & \multirow{2}{*}{$\begin{array}{l}5838 \mathrm{TC} \\
(50 \mu \mathrm{g} / \mathrm{ml})\end{array}$} & \multirow{2}{*}{$\begin{array}{l}5838 \mathrm{TC} \\
(1 \mu \mathrm{g} / \mathrm{ml})\end{array}$} & \multicolumn{2}{|c|}{ PPD $(25 \mu \mathrm{g} / \mathrm{ml})$} & \multirow[b]{2}{*}{$\begin{array}{l}\text { No } B C G \\
\text { therapy }\end{array}$} \\
\hline & & & Total & $\begin{array}{l}\text { With } \mathrm{BCG}^{\mathrm{a}} \\
\text { therapy }\end{array}$ & \\
\hline \multicolumn{6}{|l|}{ Group A } \\
\hline Number of patients reactive/total tested (\%) & $\begin{array}{l}17 / 23 \\
(74)\end{array}$ & $\begin{array}{l}8 / 14 \\
(56)\end{array}$ & $\begin{array}{l}4 / 8 \\
(50)\end{array}$ & $\begin{array}{l}1 / 1 \\
(100)\end{array}$ & $\begin{array}{l}3 / 7 \\
(43)\end{array}$ \\
\hline Number of $(+)$ tests/total tests (\%) & $\begin{array}{l}25 / 51 \\
(49)\end{array}$ & $\begin{array}{l}10 / 18 \\
(56)\end{array}$ & $\begin{array}{l}5 / 12 \\
(42)\end{array}$ & $\begin{array}{l}2 / 3 \\
(67)\end{array}$ & $\begin{array}{l}3 / 9 \\
(33)\end{array}$ \\
\hline \multicolumn{6}{|l|}{ Group B } \\
\hline Number of patients reactive/total tested (\%) & $\begin{array}{l}14 / 14 \\
(100)\end{array}$ & $\begin{array}{l}7 / 11 \\
(64)\end{array}$ & $\begin{array}{l}6 / 9 \\
(67)\end{array}$ & $\begin{array}{l}4 / 4 \\
(100)\end{array}$ & $\begin{array}{l}2 / 5 \\
(40)\end{array}$ \\
\hline Number of $(+)$ tests/total tests (\%) & $\begin{array}{l}38 / 53 \\
(72)\end{array}$ & $\begin{array}{l}8 / 16 \\
(50)\end{array}$ & $\begin{array}{l}8 / 13 \\
(62)\end{array}$ & $\begin{array}{l}5 / 6 \\
(83)\end{array}$ & $\begin{array}{l}3 / 7 \\
(43)\end{array}$ \\
\hline
\end{tabular}

a Patients who had received BCG as part of either their primary therapy or anti-tuberculosis immunization programs outside the United States

Differences between groups are not statistically significant by chi-square analysis

\section{Responses after Initial Therapy}

DCH and LMI responses after completion of initial therapy of patients with localized disease are shown in Table 6. Patients who remained free of disease (group A) retained $\mathrm{DCH}$ to recall antigens, with the exception of a single patient who was unreactive to KLH but remains disease-free after more than 2 years. However, patients who relapsed (group B) were frequently unreactive to the standard recall antigens, probably a result of immunosuppressive effects of recurrent disease or cytotoxic chemotherapy or both. In contrast, the responses to the TAAs appeared to be roughly equal for each antigen in both groups of patients. In direct LMI, all group $B$ patients were reactive to the higher concentration of tumor extract in comparison to the approximately one fourth of group A patients who remained persistently negative to this concentration of TAA. Among the pa- tients in group B who were reactive to PPD in LMI, three patients were not on immunotherapy and were not known to have received BCG elsewhere.

Table 7 summarizes the results of rosette assays following completion of therapy in group A patients. There was a general trend for counts to return toward normal. However, the percentage of $29^{\circ} \mathrm{C} \mathrm{RFC}$ remained low in $71 \%$ of the tests. Similar data were not available for the interval between completion of therapy and relapse for group B patients.

\section{Effects of Therapy on $D C H$}

We were interested in the longitudinal changes in the magnitudes of DCH responses and the effects of immunotherapy and cytotoxic radio- and chemotherapy on these responses. Sequential data from 29 group A pa- 
Table 7. Lymphocyte subpopulations after therapy of patients with localized disease in remission

\begin{tabular}{|c|c|c|c|c|c|c|c|c|}
\hline $\begin{array}{l}\text { Absolute number of } \\
\text { lymphocytes per } \mathrm{mm}^{3}\end{array}$ & $\begin{array}{l}\text { Number of } \\
\text { tests in } \\
\text { range/total tests }\end{array}$ & $(\%)$ & $\begin{array}{l}29^{\circ} \mathrm{C} \mathrm{RFC} \\
\%\end{array}$ & $\begin{array}{l}\text { Number of } \\
\text { tests in } \\
\text { range/total tests }\end{array}$ & $(\%)$ & $\begin{array}{l}4^{\circ} \mathrm{C} \mathrm{RFC} \\
\%\end{array}$ & $\begin{array}{l}\text { Number of } \\
\text { tests in } \\
\text { range/total tests }\end{array}$ & $(\%)$ \\
\hline$<500$ & $1 / 15$ & (7) & $<25$ & $1 / 14$ & (7) & $<25$ & 0 & $(0)$ \\
\hline $500-1000$ & $2 / 15$ & (13) & $25-47$ & $9 / 14$ & (64) & $25-67$ & 1 & (33) \\
\hline$>1000$ & $12 / 15$ & (80) & $>47$ & $4 / 14$ & (29) & $>67$ & 2 & (67) \\
\hline
\end{tabular}

tients, including five patients who received BCG immunotherapy, and 17 group B patients showed that radiotherapy and chemotherapy given intermittently for 6 months had no apparent suppressive effect on DCH and cessation of treatment did not appear to be associated with increased magnitude of response. Although the number of group A patients who received BCG is small and does not permit firm conclusions, no pattern of reactivity to the antigens (aside from PPD) individually or in toto clearly separated patients on immunotherapy from those receiving standard therapy alone.

\section{Discussion}

Because Ewing's sarcoma is a rare tumor, most reports concerning this neoplasm have dealt with treatment methods and results involving relatively small numbers of patients or with histopathologic descriptions of the tumor. Earlier we reported the results of LMI studies in 29 patients with Ewing's sarcoma (McCoy et al., 1977). This paper expands the previous report and includes data on the immunologic responses of Ewing's sarcoma patients and the relationship of these responses to clinical status. We also report the results of BCG immunotherapy on immunologic responses, both in patients with clinically localized disease and in those with widely disseminated disease.

Skin testing for DCH has been used extensively to assess the immune competence of cancer patients. Many studies have employed standard recall antigens, but in most studies the results of testing with these antigens have not been very useful for diagnosis or prognosis. Our results with the recall antigens SKSD, mumps, and PPD reaffirm the experiences of others: nearly all patients tested at the time of diagnosis with these substances responded alike, regardless of the extent of disease or subsequent clinical course. Lack of reactivity was associated with poor prognosis but, with few exceptions, patients with negative SKSD or mumps skin tests had readily apparent, often progressive disease and a short survival after manifestation of nonreactivity to these antigens.

Tests for DCH involving sensitization and subsequent rechallenge with an antigen to which the patient had not been previously exposed, such as DNCB, have been reported to be more sensitive prognostic indicators (Eilber and Morton, 1970; Pinsky et al., 1971; Wells et al., 1973), and our experience with KLH testing in Ewing's sarcoma is consistent with this. Employing a sensitizing dose of $2.5 \mathrm{mg}$ [ 25 times the dose needed to sensitize normals (Paul et al., 1974)] and a test dose of $0.1 \mathrm{mg}$, we found that group A patients had a much higher frequency of responses $15 \mathrm{~mm}$ or greater in diameter than did either group B or group C patients. Whether smaller sensitizing or test doses would elicit more distinct differences, as was reported with lower sensitizing doses in patients with Hodgkin's disease (Eltringham and Kaplan, 1973), is speculative.

Skin test reactivity to the Ewing's tumor extracts did not correlate with the clinical course of patients. In fact, a high proportion of patients reacted to these preparations during all phases of testing and regardless of the extent of disease. In contrast, in a study of a large group of patients with acute leukemia, Char et al. (1973) found a significantly higher percentage of positive responses to extracts of leukemic blast cells when the patients were in remission; serial tests with autologous blast extracts seemed to correlate with clinical status, with positive responses during remission becoming negative at relapse, and patients who had positive responses had a slight increase in remission duration. One possible explanation for the difference between these two studies may relate to the specificities of the tumor extracts used in DCH testing. The extracts of leukemic blast cells appeared to give disease-specific DCH reactions (Char et al., 1973). Although a high proportion of Ewing's sarcoma patients had positive skin test responses to the extracts of the 5838 tumor, these extracts were selected for intracutaneous testing because of specificity in LMI tests (McCoy et al., 1977), and the specificity of these preparations in skin testing has not been determined. In fact, two patients referred to the National Cancer Institute with Ewing's sarcoma, but subsequently found to have malignant lymphoma of bone, had positive DCH responses to the extracts prior to therapy.

In contrast to the experience of others (Papatestas et al., 1976; Riesco, 1970), we found no significant correlation between absolute lymphocyte counts at diagnosis and subsequent clinical course. Many of the patients in 
each group had low levels of $29^{\circ} \mathrm{C} \mathrm{RFC}$, as we reported earlier for lung and breast cancer patients (Oldham et al., 1976; Weese et al., 1977), and a lower proportion of patients with advanced disease had $29^{\circ} \mathrm{C}$ RFC percentages in the normal range. Absolute lymphocyte counts decreased during therapy but returned toward normal levels in patients who remained clinically free of disease; however, $29^{\circ} \mathrm{C}$ RFCs remained at low levels in nearly two-thirds of these patients.

As shown in Table 6, there was a tendency for more frequent reactivity in direct LMI testing in patients who relapsed or had tumor present. The only patients persistently unreactive in LMI were those who remained disease-free. We have noted similar trends in patients with lung and breast cancer and will report these findings in detail elsewhere. It may be that continued stimulation by residual tumor antigens is required for persistence of LMI reactivity.

We saw no noticeable effect of BCG immunotherapy on reactivity except for conversion of the PPD skin test and a higher incidence of reactivity to PPD in LMI. However, neither of these was of prognostic significance. This lack of detectable effect of immunotherapy on measurable immunologic functions is similar to that reported in acute leukemia (Leventhal et al., 1973) and in lung cancer (Oldham et al., 1976). BCG immunotherapy was well tolerated, with the only complication being a mild secondary infection of a scarification site in a 7year-old girl. Neither BCG nor BCG plus allogeneic cells appeared to alter what was usually a relentless progression toward death in patients who had metastases at time of diagnosis, nor did BCG appear to have any effect on the course of the disease in patients who relapsed. Of nine patients with localized disease, who were at high risk for relapse, four were randomized to standard treatment plus no further therapy; three have died of recurrent tumor or complications related to treatment after relapse; only one remains in remission. Of the five patients who received standard treatment plus BCG immunotherapy, only one has relapsed, a 25 -year-old male who developed multiple pulmonary metastases 18 months after the initial diagnosis. Additional patients are being accumulated to determine whether BCG immunotherapy may be of significant value in such patients at high risk for recurrence.

\section{References}

Angervall, L., Enzinger, F. M.: Extraskeletal neoplasm resembling Ewing's sarcoma. Cancer 36, 240-251 (1975)

Brereton, H. D., Simon, R., Pomeroy, T. C.: Pretreatment serum lactate dehydrogenase predicting metastatic spread in Ewing's sarcoma. Ann. intern. Med. 83, 352-354 (1975)

Char, D. H., Lepourhiet, A., Leventhal, B., Herberman, R. B.: Cutaneous delayed hypersensitivity responses to tumor-associated and other antigens in acute leukemia. Int. J. Cancer 12, 409-419 (1973)

Djeu, J., Payne, S., Alford, C., Heim, W., Pomeroy, T., Cohen, M., Oldham, R., Herberman, R.: Detection of decreased proportion of lymphocytes forming rosettes with sheep erythrocytes at $29^{\circ} \mathrm{C}$ in the blood of cancer patients: analysis of factors affecting the assay. Clin. Immunol. Immunopathol. (In press)

Eilber, F. R., Morton, D. L.: Impaired immunologic reactivity and recurrence following cancer surgery. Cancer 25, 362-367 (1970)

Eltringham, J. R., Kaplan, H. S.: Impaired delayed-hypersensitivity responses in 154 patients with untreated Hodgkin's disease. Nat. Cancer Inst. Monogr. 36, 107-115 (1973)

Falk, S., Alpert, M.: Five-year survival of patients with Ewing's sarcoma, Surg. Gynec. Obstet. 124, 319-324 (1967)

Jaffe, N., Paed, D., Traggis, D., Salian, S., Cassady, J. R.: Improved outlook for Ewing's sarcoma with combination chemotherapy (vincristine, actinomycin D and cyclophosphamide) and radiation therapy. Cancer 38, 1925-1930 (1976)

Johnson, R. E., Pomeroy, T. C.: Integrated therapy for Ewing's sarcoma. Am. J. Roentgenol., Radium Ther., and Nucl. Med. 114, 532-535 (1972)

Johnson, R. E., Pomeroy, T. C.: Evaluation of therapeutic results in Ewing's sarcoma. Amer. J. Roentgenol. 123, 583-587 (1975)

Leventhal, B. G., Le Pourheit, A., Halterman, R. H., Henderson, E. S., Herberman, R. B.: Immunotherapy in previously treated acute lymphatic leukemia. Nat. Cancer Inst. Monogr. 39, 177-187 (1973)

McCoy, J. L., Jerome, L. F., Dean, J. H., Perlin, E., Oldham, R. K., Char, D. H., Cohen, M. H., Felix, E. L., Herberman, R. B.: Inhibition of leukocyte migration by tumor associated antigens in soluble extracts of human malignant melanoma. J. nat. Cancer Inst. 55, 19-23 (1975)

McCoy, J. L., Jerome, L. J., Cannon, G. B., Pomeroy, T. C., Connor, R. J., Oldham, R. K., Weese, J. L., Herberman, R. B.: Leukocyte migration inhibition in patients with Ewing's sarcoma by $3 \mathrm{M} \mathrm{KCl}$ extracts of fresh and tissue cultured Ewing's sarcomas. J. nat. Cancer Inst. 59, 1119-1125 (1977)

Oldham, R. K., Weese, J. L., Herberman, R. B., Perlin, E., Mills, M., Heim, W., Blom, J., Green, D., Reid, J., Bellinger, S., Law, I., McCoy, J. L., Dean, J. H., Cannon, G. B., Djeu, J.: Immunologic monitoring and immunotherapy in carcinoma of the lung. Int. J. Cancer 18, 739-749 (1976)

Oren, M. E., Herberman, R. B.: Delayed cutaneous hypersensitivity reactions to membrane extracts of human tumor cells. Clin. exp. Immunol. 9, 45-56 (1971)

Papatestas, A. E., Lesnick, G. J., Genkins, G., Aufses, A. H., Jr.: The prognostic significance of peripheral lymphocyte counts in patients with breast carcinoma. Cancer 37, 164-168 (1976)

Paul, S., Kenny, A. B., Hitzig, W. H.: Immune response to keyholelimpet hemocyanin in the human. Int. Arch. Allergy 47, 155-160 (1974)

Pinsky, C. M., Oettgen, H. F., El Domeiri, A., Old, L. J., Beattie, E. J., Burchenal, L. H.: Delayed hypersensitivity reactions in patients with cancer. Proc. Amer. Ass. Cancer Res. 12, 100 (1971)

Pomeroy, T. C., Johnson, R. E.: Prognostic factors for survival in Ewing's sarcoma. Amer. J. Roentgenol. 123, 598-505 (1975)

Riesco, O.: Five-year cancer cure - relation to total amount of peripheral lymphocytes and neutrophiles. Cancer 25, 135-140 (1970)

Rosen, G., Wollner, N., Tan, C., Wu, S. J., Hajdu, S. I., Cham, W., D'Angio, G. J., Murphy, M. L.: Disease-free survival in children with Ewing's sarcoma treated with radiation therapy and adjuvant four-drug sequential chemotherapy. Cancer 33, 384-393 (1974) 
Sokal, J.: Measurement of delayed skin-test responses. New. Engl. J. Med. 293, 501-502 (1975)

Sutow, W. W., Martin, R. G.: Ewing's sarcoma. In: Cancer Med. Holland J. F., Frei E. (Eds.), pp. 1873-1875. Philadelphia, Pa.: Lea and Febiger 1974

Weese, J. L., Oldham, R. K., Tormey, D. C., Barlock, A. L., Morales, A., Cohen, M. H., Alford, T. C., Shorb, P. E., Tsangaris, N. T., West, W. H., Cannon, G. B., Dean, J. H., Djeu, J., McCoy, J. L., Herberman, R. B.: Immunologic monitoring in carcinoma of the breast. Surg. Gynec. Obstet. 145, 209-218 (1977)

Wells, S. A., Jr., Burdick, J. F., Christiansen, C., Ketcham, A. S., Adkins, P. C.: Demonstration of tumor-associated delayed cuta- neous hypersensitivity reactions in patients with lung cancer and in patients with carcinoma of the cervix. Nat. Cancer Inst. Monogr. 37, 197-203 (1973)

West, W. H.: E-rosette formation in immunodiagnosis. In: Immunodiagnosis of Cancer. Herberman, R. B., McIntire, K. R. (Eds.), New York: Marcel Dekker (in press, 1978)

West, W. H., Sienknecht, C. W., Townes, A. S., Herberman, R. B.: Performance of a rosette assay between lymphocytes and sheep erythrocytes at elevated temperatures to study patients with cancer and other diseases. Clin. Immunol. Immunopathol. 5, 60-66 (1976)

Received October 12, 1977/Accepted February 2, 1978 